\title{
Clergyman, Cleric, and Religious Leader: An Experiment on Alternative Reference Individuals for the Free Expression Items*
}

\author{
Stephen L. Morgan \\ Johns Hopkins University \\ GSS Methodological Report No. 128
}

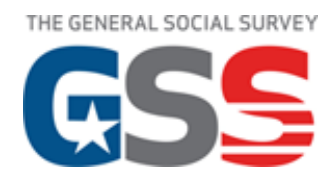

May 2019

* I thank the GSS Board of Overseers for the Fall 2018 discussion that prompted this investigation as well as Tom Smith for comments on a first draft of the report. The experimental data were collected by TimeSharing Experiments for the Social Sciences, NSF Grant 0818839, Jeremy Freese and James Druckman, Principal Investigators. 


\section{INTRODUCTION}

Following upon the foundational work of Samuel Stouffer in his 1955 book Communism, Conformity, and Civil Liberties, the General Social Survey (GSS) has measured support for free expression in the United states since 1972 (see Davis 2012). Although some of Stouffer's original items have been retained, variants on his items have been developed in response to changes in the contested domains of free expression.

The five long-run GSS reference individuals whose free expression is placed before the respondent are: an atheist, a racist, a communist, a militarist, and a homosexual. These oneword descriptions, although used in the literature and encoded in the GSS mnemonic variable names, can be a bit misleading. For example, the "atheist" is "somebody who is against all churches and religion," not someone who denies the existence of all deities. The mode and arena of free expression for these reference individuals are speaking in the community, teaching in a college or university, and having a book in the local public library.

For the 2008 GSS, a sixth reference individual was introduced, "a Muslim clergyman who preaches hatred of the United States." Table 1 (see next page) presents the order and wording of the 18 items, as they have been fixed from 2008 through 2018.

For the 2020 GSS, a review of the free expression items suggested revisions to "a Muslim clergyman who preaches hatred of the United States," as part of a broader effort by the GSS Board to reassess all GSS items that are gender-specific in some way. Two gender-neutral alternatives were discussed, "an Islamic cleric who preaches hatred of the United States" and "an Islamic religious leader who preaches hatred of the United States."

For the reasons detailed below, it is possible that a switch to "an Islamic cleric who preaches hatred of the United States" could prompt an undesirable discontinuity in response patterns, beyond what could be expected to result from a gender-neutral substitution. If some GSS respondents are more likely to suspect that the referenced Islamic cleric has a connection to terrorism, the elicited response may be a mixture of opposition to free expression and a perceived fear of physical violence, with more weighting on the latter. In contrast, "an Islamic religious leader who preaches hatred of the United States" may be preferable, if it is the case that GSS respondents are no more likely to infer a threat to their security than is the case for "a Muslim clergyman who preaches hatred of the United States."

In this report, I offer two sets of results to inform decisions about the questionnaire for the 2020 GSS. First, to set the background, I use GSS data from 2008 through 2018 to summarize levels and changes in attitudes toward free expression for all six existing reference individuals. Second, I offer results from a three-armed experiment that compares "Muslim clergyman" to the two alternatives of "Islamic cleric" and "Islamic religious leader." The experimental data were collected over the web in January and February of 2019 as part of the AmeriSpeak panel. 
Table 1. The GSS Items on Free Expression as of 2018

Mode and Arena of Free Expression

Speech in your community Teach in college

Book in public library

\begin{tabular}{l} 
Reference Individual \\
\hline Atheist \\
somebody who is \\
against all churches and \\
religion \\
Racist \\
a person who believes \\
that Blacks are \\
genetically inferior
\end{tabular}

If such a person wanted to

make a speech in your

(city/town/community)

against churches and

religion, should he be

allowed to speak, or not?

If such a person wanted to make a speech in your community claiming that Blacks are inferior, should he be allowed to speak, or not?

\section{Communist \\ a man who admits he is a Communist}

Suppose this admitted Communist wanted to make a speech in your community. Should he be allowed to speak, or not?

If such a person wanted to make a speech in your community, should he be allowed to speak, or not?

\section{Homosexual \\ a man who admits that he is homosexual}

Suppose this admitted homosexual wanted to make a speech in your community. Should he be allowed to speak, or not?

If such a person wanted to make a speech in your community preaching hatred of the United States, should he be allowed to speak, or not?
Should such a person be allowed to teach in a college or university, or not?

Should such a person be allowed to teach in a college or university, or not?

Suppose he is teaching in a college. Should he be fired, or not?

Should such a person be allowed to teach in a college or university, or not?

Should such a
person be
allowed to teach
in a college or
university, or
not?

Should such a person be allowed to teach in a college or university, or not?
If some people in your community suggested that a book he wrote against churches and religion should be taken out of your public library, would you favor removing this book, or not?

If some people in your community suggested that a book he wrote which said Blacks are inferior should be taken out of your public library, would you favor removing this book, or not?

Suppose he wrote a book which is in your public library. Somebody in your community suggests that the book should be removed from the library. Would you favor removing it, or not?

Suppose he wrote a book advocating doing away with elections and letting the military run the country. Somebody in your community suggests that the book be removed from the public library. Would you favor removing it, or not?

If some people in your community suggested that a book he wrote in favor of homosexuality should be taken out of your public library, would you favor removing this book, or not?

If some people in your community suggested that a book he wrote which preaches hatred of the United States should be taken out of your public library, would you favor removing this book, or not? 


\section{RESULTS FROM THE GSS}

Table 2 presents the percentages of 2018 GSS respondents who offer tolerant responses to the 18 free expression items (i.e., approval of the expression). ${ }^{1}$ Tolerance is lowest for the Muslim clergyman, followed by the racist, and then other reference individuals. Tolerance for teaching in college is considerably lower for four of the six reference individuals: the atheist, racist, militarist, and Muslim clergyman.

Table 2. Percent Tolerant of Three Types of Free Expression for Six Reference Individuals, 2018 GSS

\begin{tabular}{|c|c|c|c|c|c|c|c|c|c|}
\hline \multirow{2}{*}{$\begin{array}{l}\text { Reference } \\
\text { individual }\end{array}$} & \multicolumn{3}{|c|}{ Speech in your community } & \multicolumn{3}{|c|}{ Teach in college } & \multicolumn{3}{|c|}{ Book in public library } \\
\hline & Perc. & s.e. & 95\% c.i. & Perc. & s.e. & 95\% c.i. & Perc. & s.e. & 95\% c.i. \\
\hline Atheist & 82.2 & (1.5) & {$[79.2,85.2]$} & 70.3 & (1.9) & {$[66.6,74.1]$} & 81.1 & (1.4) & {$[78.3,83.8]$} \\
\hline Racist & 58.6 & (1.7) & {$[55.2,62.0]$} & 43.9 & $(1.8)$ & {$[40.3,47.5]$} & 62.0 & (1.9) & {$[58.1,65.8]$} \\
\hline Communist & 70.9 & (1.8) & {$[67.5,74.4]$} & 68.0 & (1.5) & {$[65.1,70.9]$} & 75.2 & (1.7) & {$[71.9,78.5]$} \\
\hline Militarist & 73.4 & (1.6) & {$[70.3,76.6]$} & 61.8 & (1.4) & {$[58.9,64.6]$} & 76.6 & (1.4) & {$[73.9,79.4]$} \\
\hline Homosexual & 90.1 & (1.0) & {$[88.0,92.1]$} & 89.4 & (1.0) & {$[87.5,91.4]$} & 86.6 & (1.1) & {$[84.5,88.7]$} \\
\hline Muslim clergyman & 48.3 & (1.7) & {$[45.0,51.6]$} & 36.0 & $(1.8)$ & {$[32.4,39.6]$} & 53.3 & (1.8) & {$[49.8,56.8]$} \\
\hline
\end{tabular}

Notes: The $N$ varies between 1,465 and 1,562 based on the outcome analyzed.

Table 3 presents the corresponding changes per year in the percentages since 2008, estimated from an underlying logit model with a linear constraint on change. Increases in tolerance are steady and substantial for the atheist, communist, militarist, and homosexual, with some slight variation across arena. For the racist, change is in the opposite direction, with little or no change for a speech in the community. Finally, for the Muslim clergyman, tolerance has increased very slightly. ${ }^{2}$

Table 3. Change in Percent Tolerant, 2008-2018 GSS

\begin{tabular}{|c|c|c|c|c|c|c|c|c|c|}
\hline \multirow{3}{*}{$\begin{array}{l}\text { Reference } \\
\text { individual }\end{array}$} & \multirow{2}{*}{\multicolumn{3}{|c|}{$\begin{array}{l}\text { Speech in your community } \\
\Delta \text { per }\end{array}$}} & \multicolumn{3}{|c|}{ Teach in college } & \multicolumn{3}{|c|}{ Book in public library } \\
\hline & & & & $\Delta$ per & & & $\Delta$ per & & \\
\hline & year & s.e. & $\mathrm{p}$ value & year & s.e. & $\mathrm{p}$ value & year & s.e. & $\mathrm{p}$ value \\
\hline Atheist & 0.4 & $(0.2)$ & 0.007 & 0.7 & $(0.2)$ & 0.000 & 0.5 & $(0.2)$ & 0.000 \\
\hline Racist & -0.1 & $(0.2)$ & 0.530 & -0.4 & $(0.2)$ & 0.025 & -0.4 & $(0.2)$ & 0.016 \\
\hline Communist & 0.4 & $(0.2)$ & 0.012 & 0.6 & $(0.2)$ & 0.000 & 0.4 & $(0.2)$ & 0.011 \\
\hline Militarist & 0.6 & $(0.2)$ & 0.001 & 0.7 & $(0.2)$ & 0.000 & 0.4 & $(0.2)$ & 0.020 \\
\hline Homosexual & 0.6 & $(0.1)$ & 0.000 & 0.8 & $(0.1)$ & 0.000 & 0.8 & $(0.1)$ & 0.000 \\
\hline Muslim clergyman & 0.3 & $(0.2)$ & 0.059 & 0.3 & $(0.2)$ & 0.089 & 0.1 & $(0.2)$ & 0.686 \\
\hline
\end{tabular}

Notes: The $N$ varies between 7,298 and 7,463 based on the outcome analyzed.

\footnotetext{
${ }^{1}$ For the results in this report, "don't know" responses are treated as missing. For the GSS analysis, the data are weighted with the non-response adjusted weight, wtssnr.

${ }^{2}$ Increases in 2018 appear to suggest the beginning of a trend toward increased tolerance for the Muslim clergyman. Limiting the analysis to 2008 through 2016, the rates of change that correspond to the last row of Table 3 are instead $0.1,0.3$, and -0.1 .
} 


\section{EXPERIMENTAL DESIGN}

[ This section is drawn from the project registration "A Question-Wording Experiment on Support for Free Expression," which was posted to the website of the Open Science Framework (see https://osf.io/jaxdy/) before the experiment was conducted. The rationale for the preregistration of experiments is explained in Nosek et al. (2018); see also https://cos.io/prereg/.]

\section{Preregistered Design and Hypotheses}

Overview. The study is a three-armed, equal-probability, randomized questionwording experiment on support for free expression. The treatment conditions are defined by alternative characterizations of a reference individual whose free expression could be subject to limitation because of perceived individual or societal threat from the content or delivery of the expression. The survey respondents in the study are asked to express attitudes on whether limitations to free expression should be imposed in three alternative arenas: speaking to your community, teaching in a college or university, or having a book in your public library. The baseline reference individual is the reference individual for the 2008-18 General Social Surveys (GSS), "a Muslim clergyman who preaches hatred of the United States." The two alternatives introduced for this experiment are "an Islamic cleric who preaches hatred of the United States" and "an Islamic religious leader who preaches hatred of the United States."

Goal of the study. Although the hypotheses articulated below are of general social scientific interest, an additional goal of the study is to inform an upcoming decision by the Board of Overseers of the GSS on revisions to question wording for the 2020 GSS. My expectation is that the 2020 GSS will have a randomized split-ballot alternative wording with either "Islamic cleric" or "Islamic religious leader" as a single alternative to the existing "Muslim clergyman." Although the Board will make the decision, my prediction is that "Islamic religious leader" will be favored because it is broad, simple to understand, and will be judged less likely to change in perceived meaning in the future than "Islamic cleric." In addition, I predict that the existing "Muslim clergyman" will be retired from the survey instrument, possibly as soon as the 2022 GSS, because it is somewhat awkward and genderspecific. Altogether, this supplementary operational goal of the study, therefore, is to inform the decision of the Board so that arguments in favor of particular question wordings are informed by reasonable forecasts of the consequences for marginal distributions of any changes.

Target population and intended sample. The target population is the general population of adults in the US, as defined for NORC's AmeriSpeak. The intended sample is 2,000 respondents.

Mode of administration. The questions are "self-administered," in this case read and answered online, as presented by NORC's AmeriSpeak online instrument. 
Additional measures collected. NORC's AmeriSpeak delivers a standard set of “demographic variables," which also include party identification, political ideology, and religious preference. (In addition, because this is a TESS short study, it is likely to be combined with and possibly preceded by another set of questions for another study. These other questions may induce a context effect on this experiment. I do not know what such other studies might be, nor whether the measures they collect will be shared with me.)

Treatment assignment. The three experimental conditions are randomly assigned with equal probability, using a randomization procedure implemented by NORC's programming for AmeriSpeak.

\section{The Three Treatments (with Alternative Wordings in Red Bold and Underlined)}

\section{Condition 1 (baseline GSS 2008-2018 wording)}

There are always some people whose ideas are considered bad or dangerous by other people. Consider a Muslim clergyman who preaches hatred of the United States.

1. If such a person wanted to make a speech in your community preaching hatred of the United States, should he be allowed to speak, or not?

Yes, allowed

Not allowed

Don't know

2. Should such a person be allowed to teach in a college or university, or not?

Yes, allowed

Not allowed

Don't know

3. If some people in your community suggested that a book he wrote which preaches hatred of the United States should be taken out of your public library, would you favor removing this book, or not?

Favor

Oppose

Don't know

\section{Condition 2 (Islamic cleric as an alternative)}


There are always some people whose ideas are considered bad or dangerous by other people. Consider an Islamic cleric who preaches hatred of the United States.

1. If such a person wanted to make a speech in your community preaching hatred of the United States, should this person be allowed to speak, or not?

Yes, allowed

Not allowed

Don't know

2. Should such a person be allowed to teach in a college or university, or not?

Yes, allowed

Not allowed

Don't know

3. If some people in your community suggested that a book written by this person which preaches hatred of the United States should be taken out of your public library, would you favor removing this book, or not?

Favor

Oppose

Don't know

\section{Condition 3 (Islamic religious leader as an alternative)}

There are always some people whose ideas are considered bad or dangerous by other people. Consider an Islamic religious leader who preaches hatred of the United States.

1. If such a person wanted to make a speech in your community preaching hatred of the United States, should this person be allowed to speak, or not?

Yes, allowed

Not allowed

Don't know

2. Should such a person be allowed to teach in a college or university, or not?

Yes, allowed

Not allowed

Don't know 
3. If some people in your community suggested that a book written by this person which preaches hatred of the United States should be taken out of your public library, would you favor removing this book, or not?

Favor

Oppose

Don't know

\section{Hypotheses}

Null hypothesis. All three treatment conditions will yield appreciably similar responses.

Rationale. Given that the most salient and explicitly threatening part of the battery of items is "preaches hatred of the United States," the salience of the reference individual is too low, in relative terms, to matter to respondents. In addition, the "Islamic cleric" and "Islamic religious leader" may be interpreted as little more than non-gender-specific equivalences for "Muslim clergyman" (because clerics are, by many dictionary definitions, simply members of the clergy, and because clerics and members of the clergy are types of religious leaders). Finally, the word "Islamic" is only a slight alternative to "Muslim," while the "man" portion of "clergyman" may already be elided by the ears/eyes of respondents (i.e., as antiquated speech that hangs around because it is preferable to ungainly substitutes, such as "clergyperson," that are not used commonly in speech).

Alternative hypothesis 1 (unconditional). Respondents will extend fewer opportunities for free expression to the "Islamic cleric" than to the "Muslim clergyman."

Rationale. Respondents who are attuned to media portrayals of Islam may be more likely to associate an "Islamic cleric" with terrorism and violence, above and beyond the threat conveyed already by the more abstract "preaches hatred of the United States." Any such respondents may perceive even greater threat because of the inference that terrorism could be inspired by the referenced "Islamic cleric," perhaps through the specific content of the free speech (and which, by inference, could be interpreted as direct incitement to the type of imminent lawlessness and violence that has not been seen as protected free speech by US courts). The term "Muslim clergyman" would seem to have a less clear relative valence. On the one hand, some respondents, at the time this study is to be conducted, may associate it with the "Muslim ban" that was a major media and political topic in 2017 and 2018. On the other hand, for respondents who are less attuned to current events and/or have smaller vocabularies, 
"clergyman" may elicit some baseline positive sentiment because the word "clergy" is frequently used with reference to Christianity.

Alternative hypothesis 1-a (partisanship interaction). This effect will be strongest among those who identify as Republicans, or leaning Republicans (in comparison to Democrats and leaning Democrats) because (a) Republican political elites are more likely to associate Islam with terrorism and violence and (b) those who identify as Republicans are either influenced by Republican political elites or are attracted to Republican political elites.

Alternative hypothesis 1-b (arena interaction). This effect will be strongest when the threat of imminent violence is possible, such as for the first question on a speech in the community.

Alternative hypothesis 2 (unconditional). Respondents will extend more opportunities for free expression to the "Islamic religious leader" than to the "Islamic cleric."

Rationale. If a threat-of-violence mechanism is triggered by the description of the reference individual, then the "Islamic religious leader" may be granted more opportunities for free expression than the "Islamic cleric" if "Islamic religious leader" triggers fewer implicit associations with the threat of violence. A "religious leader" is a more generic category and a broader title.

Alternative hypotheses 2-a and 2-b. Direct analogues to alternative hypotheses 1-a and 1-b.

Alternative hypothesis 3 (unconditional). Respondents will extend (slightly) fewer opportunities for free expression to the "Islamic religious leader" than to the "Muslim clergyman."

Rationale. The basic rationale is the same as for alternative hypothesis 1 , but the effect is likely weaker because of the rationale for alternative hypothesis 2 . The effect would be present if the positive sentiment induced by "clergy" is greater than the negative sentiment induced by "Muslim." Little prior information is available to assess these possibilities, which, in the current context, may be especially complex because of recent debates over the constitutionality of the proposed "Muslim ban" to the US (and how those debates interact with sentiment toward alternative political leaders in the US). It is possible that this hypothesis will not be supported because a diverse coalition of individuals will extend more opportunities for free expression to the "Muslim clergyman" (such as conservative Christians who have warm feelings for all members of the clergy, along with libertarians and progressives who directly oppose the Muslim ban). 


\section{Alternative hypotheses 3-a and 3-b. Direct analogues to alternative hypotheses 1-a and 1-b.}

\section{Additional Discussion of the Design and Hypotheses}

The hypotheses are somewhat specific to the United States. In a country where Islam is well understood, an "Islamic cleric" could yield an alternative response pattern because the "cleric" may more commonly reference an individual who is an Islamic scholar with recognized expertise in interpreting Islamic texts. In addition, the reverence for insight and wisdom of such scholars is not necessarily granted to a "religious leader," who may be more likely to genuinely threaten violence because of adherence to an especially politicized form of Islam, or ongoing between-state conflict. ${ }^{3}$

Because of the following factors, there is reason to expect that even the baseline reference individual will elicit alternative distributions of support for free expression than is the case for the GSS (where the implicit reference point is the 2018 GSS):

1. The online mode of the NORC AmeriSpeak differs from the face-to-face (and, when necessary, phone) mode of the GSS.

2. The NORC AmeriSpeak sample is constructed in an alternative fashion and has some systematic differences from the GSS target population (e.g., how nonEnglish speakers are handled and so forth).

3. The NORC AmeriSpeak instrument has a different context. The GSS items for the "Muslim clergyman" follow other batteries of similar items for reference individuals, such as the Stoufferian "admitted communist."

\footnotetext{
${ }^{3}$ In many such countries, where survey instruments would be written in a language other than English, comparative analysis would require a translation of the reference individual. Based on discussions with colleagues, I believe that both "Islamic cleric" and "Islamic religious leader" have available translations in many countries where Islam is a common religion. It may be that "Muslim clergyman" would be translated in the same way as "Islamic cleric."
} 


\section{Results of the Experiment}

Details of the data collection are provided in the AmeriSpeak field report, posted at this URL link https://osf.io/bf5mh/. The total $N$ for the experiment was 2,019 respondents, although missing data reduces some of the analysis below to effectives $N$ s as low as 2,002.

Table 4 presents percent tolerant for the three experimental conditions. For the speech and library arenas, the results for the Muslim clergyman are very close to the results for the GSS: 48.3 and 52.5 percent for the experiment in comparison to 48.3 and 53.3 percent for the GSS, respectively (see Table 1). However, the experiment suggested a lower level of support for teaching in a college or university: 28.4 percent for the experiment in comparison to 36.0 percent for the GSS. It is plausible that this difference is a context effect. For the GSS, the Muslim clergyman items are delivered after all of the other reference individuals. By then, the respondent has likely determined that the domain being investigated is something like support for free speech, not employment patterns. However, for the AmeriSpeak experiment, no prior reference individuals are offered. And, because "clergyman" is a type of occupation, it is possible that some AmeriSpeak respondents are expressing a view that teaching in college should be reserved those in teaching occupations, not religious occupations. The same context effect could be in place for both the Islamic cleric and the Islamic religious leader.

Table 4. Percent Tolerant for Three Types of Free Expression by Three Reference Individuals, 2019 NORC AmeriSpeak Experiment

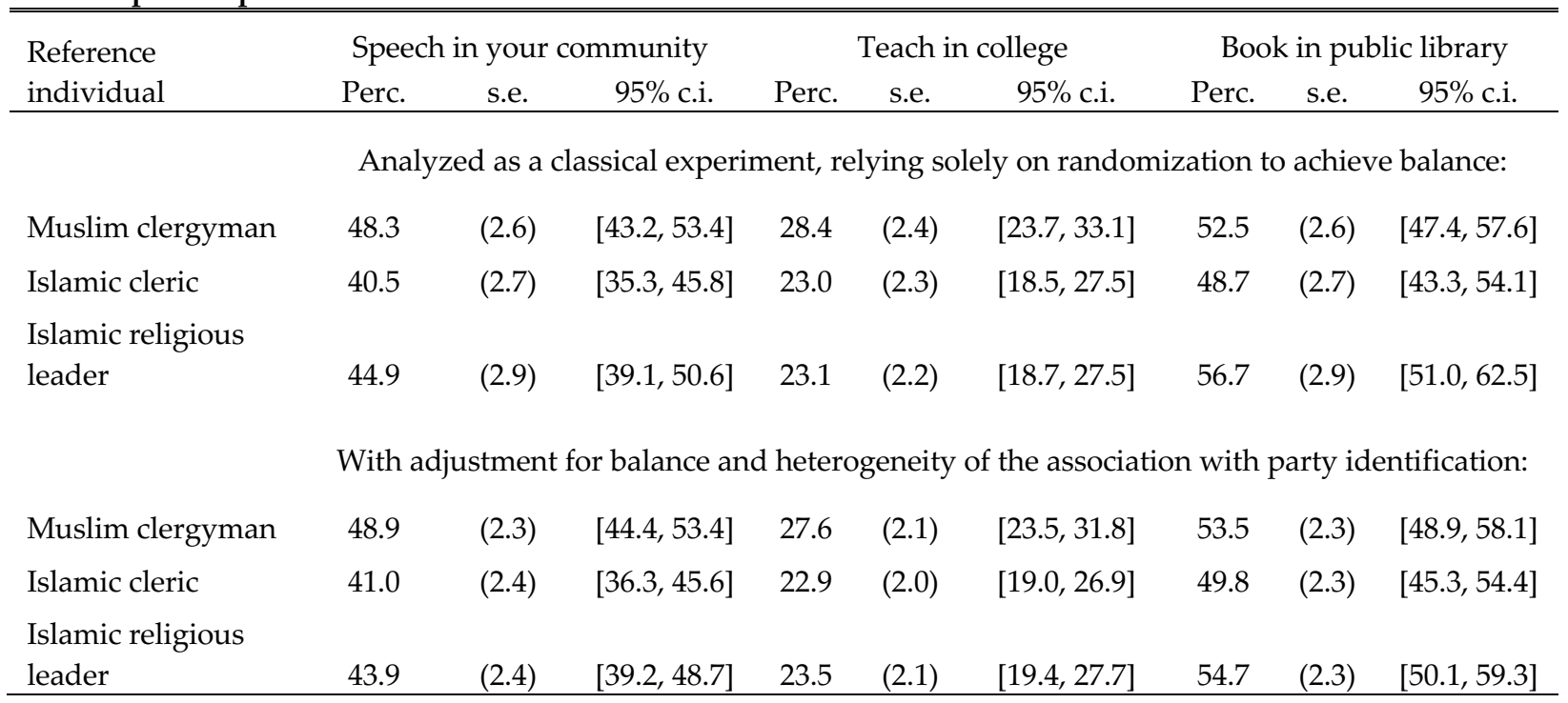

Source: Morgan's tabulations of the AmeriSpeak implementation of study "TESS 030 - Morgan."

Notes: The $N$ varies between 2,002 and 2,019 because of non-responses to the outcome questions and based on whether covariates are used in the models. The distribution across the three treatments was meant to be equal (i.e., resulting in 673 cases each), but in practice the randomization resulted in a distribution with 709, 660, and 650 respondents in each of the three conditions. This was a somewhat unlikely realized distribution. The probability of a random allocation of 2,019 cases producing a result with a treatment condition $N$ as high as 709 is only 0.14 . 
Overall, Table 4 shows that tolerance is slightly higher for the Muslim clergyman than for the Islamic cleric, with the Islamic religious leader in between. Table 5 presents tests for these differences across the three experimental conditions. The differences suggest weak evidence against the global null hypothesis, as there are meaningful differences that cannot be easily attributed to random variation from sampling or treatment assignment. In line with hypotheses 1 and 1-b, tolerance for the Islamic cleric is lower than for the Muslim clergyman, and more so in face-to-face modes of expression. The analogous hypotheses 2, 2-b, 3, and 3-b have very weak support, if any at all.

Table 5. Differences in Percent Tolerant for Three Types of Free Expression by Three Reference Individuals, 2019 NORC AmeriSpeak Experiment

\begin{tabular}{|c|c|c|c|c|c|c|c|c|c|}
\hline \multirow[b]{2}{*}{$\begin{array}{l}\text { Treatment } \\
\text { difference }\end{array}$} & \multicolumn{3}{|c|}{ Speech in your community } & \multicolumn{3}{|c|}{ Teach in college } & \multicolumn{3}{|c|}{ Book in public library } \\
\hline & $\begin{array}{l}\text { Diff in } \\
\text { Perc. }\end{array}$ & s.e. & 95\% c.i. & $\begin{array}{c}\text { Diff in } \\
\text { Perc. }\end{array}$ & s.e. & 95\% c.i. & $\begin{array}{c}\text { Diff in } \\
\text { Perc. }\end{array}$ & s.e. & 95\% c.i. \\
\hline
\end{tabular}

Analyzed as a classical experiment, relying solely on randomization to achieve balance:

Islamic cleric -

$\begin{array}{lllllllll}\text { Muslim clergyman } \quad-7.8 \quad(3.7) & {[-15.1,-0.5]} & -5.4 & (3.3) & {[-12.0,1.1]} & -3.8 & (3.8) & {[-11.2,3.6]}\end{array}$

Islamic religious

leader -

Muslim clergyman $\quad-3.4 \quad(3.9) \quad[-11.1,4.2] \quad-5.3 \quad(3.3) \quad[-11.7,1.1] \quad 4.2 \quad(3.9) \quad[-3.4,11.9]$

Islamic religious

leader -

Islamic cleric

$\begin{array}{llllllll}4.3 & (4.0) \quad[-3.4,12.1\end{array} \quad 0.1 \quad(3.2) \quad[-6.2,6.4] \quad 8.0 \quad[0.0 \quad(4.0) \quad[0.2,15.9]$

With adjustment for balance and heterogeneity of the association with party identification:

Islamic cleric -

Muslim clergyman

$-7.9$

[-14.5, -1.4]

$-4.7$

$[-10.4,1.0]$

$-3.7$

(3.3)

[-10.2, 2.8]

Islamic religious

leader -

Muslim clergyman

$-5.0$

[-11.5, 1.6]

$-4.1$

(3.0)

$[-9.9,1.7]$

1.2

(3.3) $[-5.4,7.7]$

Islamic religious

leader -

Islamic cleric 3.0

(3.4)

$[-3.7,9.6]$

0.6

(3.0)

$[-5.2,6.4]$

4.8

(3.3) $[-1.6,11.3]$

Source: See Table 4.

Notes: See Table 4. 
Table 6 presents differences that are relevant to evaluations of hypotheses $1 \mathrm{a}, 2 \mathrm{a}$, and $3 \mathrm{a}$, regarding partisan variation in the treatment effects evaluated for Table 5 . One way to evaluate these hypotheses is to test for variation in the association between partisanship and tolerance, across each of the three treatments. With a standard seven-category party identification scale -from strong Democrat at 1 to strong Republican at 7 - the hypotheses suggest that partisanship, for example, will be most strongly negatively associated with tolerance for the Islamic cleric in the speech domain. Table 6 shows that the strength of identification as a Republican is consistently associated with lower tolerance, but variation across treatments and arenas is weakly patterned. These results, therefore, provide little or no evidence to support hypotheses $1 \mathrm{a}, 2 \mathrm{a}$, and $3 \mathrm{a}$, thereby suggesting that revision to the reference individual is unlikely to generate discontinuous change differentially across party identification. An experiment with a larger sample of respondents could provide enough additional precision to reveal a pattern that suggests otherwise.

\begin{tabular}{|c|c|c|c|c|c|c|c|c|c|}
\hline \multirow[b]{2}{*}{ Treatment } & \multicolumn{3}{|c|}{ Speech in your community } & \multicolumn{3}{|c|}{ Teach in college } & \multicolumn{3}{|c|}{ Book in public library } \\
\hline & $\begin{array}{l}\text { Coef. on } \\
\text { party id }\end{array}$ & s.e. & 95\% c.i. & $\begin{array}{l}\text { Coef. on } \\
\text { party id }\end{array}$ & s.e. & $95 \%$ c.i. & $\begin{array}{l}\text { Coef. on } \\
\text { party id }\end{array}$ & s.e. & $95 \%$ c.i. \\
\hline $\begin{array}{l}\text { Muslim } \\
\text { clergyman }\end{array}$ & -3.8 & $(1.1)$ & {$[-5.9,-1.7]$} & -3.8 & $(1.1)$ & {$[-5.9,-1.7]$} & -2.8 & $(1.2)$ & {$[-5.2,-0.3]$} \\
\hline Islamic cleric & -2.2 & (1.1) & {$[-4.3,-0.0]$} & -2.2 & $(1.1)$ & {$[-4.3,-0.0]$} & -1.7 & $(1.4)$ & {$[-4.5,1.1]$} \\
\hline $\begin{array}{l}\text { Islamic religious } \\
\text { leader }\end{array}$ & -1.0 & $(1.2)$ & {$[-3.3,1.2]$} & -1.0 & $(1.2)$ & {$[-3.3,1.2]$} & -5.6 & $(1.2)$ & {$[-8.0,-3.3]$} \\
\hline
\end{tabular}

Source: See Table 4.

Notes: See Table 4.

\section{CONCLUSIONS}

The goal of the AmeriSpeak experiment was to determine which of two alternatives the Islamic cleric or the Islamic religious leader - would be a better choice for a split-ballot experiment alongside the Muslim clergyman for the 2020 GSS (under the assumption that the GSS board is predisposed to test one or the other against the gender-specific Muslim clergyman).

As an alternative to the Muslim clergyman, respondents appear slightly less tolerant of the Islamic cleric, but only clearly so in the speech domain. The Islamic religious leader produces a response pattern that is closer to the one elicited for the Muslim clergyman.

This pattern tips the scales in favor of the Islamic religious leader rather than the Islamic cleric, if the goal of the GSS board remains one of finding a permanent alternative for the Muslim clergyman. A split-ballot experiment for the 2020 GSS that compares the responses to the Muslim clergyman to those for the Islamic religious leader would enable a more direct test 
of whether the two reference individuals are similar enough than migrating to only the Islamic religious leader is sensible. If, however, the response pattern is different, then a case can be made for continuing the split-ballot experiment for the 2022 GSS, or indefinitely in order to establish as second time series. 


\section{References Cited}

Davis, James A. 2012. “On the Seemingly Relentless Progress in Americans' Support for Free Expression, 1972-2006." Pp. 19-37 in Social Trends in American Life: Findings from the General Social Survey since 1972, edited by P. V. Marsden. Princeton: Princeton University Press.

Nosek, Brian A., Charles R. Ebersole, Alexander C. DeHaven, David T. Mellor. 2018. “The Preregistration Revolution." Proceedings of the National Academy of Sciences 115:26002606. doi: 10.1073/pnas.1708274114

Stouffer, Samuel A. 1955. Communism, Conformity, and Civil Liberties: A Cross-Section of the Nation Speaks Its Mind. Garden City: Doubleday. 